Meta

Journal des traducteurs

Translators' Journal

\title{
Investigating the Complementary Polysemy and the Arabic Translations of the Noun Destruction in EAPCOUNT
}

\section{Hammouda Salhi}

Volume 58, numéro 1, avril 2013

URI : https://id.erudit.org/iderudit/1023818ar

DOI : https://doi.org/10.7202/1023818ar

Aller au sommaire du numéro

\section{Éditeur(s)}

Les Presses de l’Université de Montréal

ISSN

0026-0452 (imprimé)

1492-1421 (numérique)

Découvrir la revue

Citer cet article

Salhi, H. (2013). Investigating the Complementary Polysemy and the Arabic Translations of the Noun Destruction in EAPCOUNT. Meta, 58(1), 227-246. https://doi.org/10.7202/1023818ar
Résumé de l'article

Le présent article aborde un sujet à la croisée de la traductologie, de la sémantique lexicale et de la linguistique de corpus. Son objectif général est de montrer comment la traductologie peut tirer profit de la sémantique lexicale et de la linguistique de corpus. Plus spécifiquement, il vise à capturer le comportement sémantique et pragmatique du substantif destruction et de ses différentes traductions en arabe. Les données sont extraites d'un corpus parallèle anglais-arabe, constitué de textes de l'ONU et de leurs traductions (EAPCOUNT). L'analyse les données recueillies met en relief la polysémie du mot destruction dans la mesure où un certain nombre d'alternances sémantiques et pragmatiques peuvent être saisies. Ces résultats sont discutés dans le cadre de la théorie du Lexique Génératif (LG) de James Pustejovsky. L'article se conclut sur certaines propositions concrètes pour améliorer la relation et la coopération mutuelle entre linguistes et traducteurs. 


\title{
Investigating the Complementary Polysemy and the Arabic Translations of the Noun Destruction in EAPCOUNT
}

\author{
HAMMOUDA SALHI \\ University of Tunis El Manar, Tunisia \\ hammouda_s@hotmail.com
}

\section{RÉSUMÉ}

Le présent article aborde un sujet à la croisée de la traductologie, de la sémantique lexicale et de la linguistique de corpus. Son objectif général est de montrer comment la traductologie peut tirer profit de la sémantique lexicale et de la linguistique de corpus. Plus spécifiquement, il vise à capturer le comportement sémantique et pragmatique du substantif destruction et de ses différentes traductions en arabe. Les données sont extraites d'un corpus parallèle anglais-arabe, constitué de textes de l'ONU et de leurs traductions (EAPCOUNT). L'analyse les données recueillies met en relief la polysémie du mot destruction dans la mesure où un certain nombre d'alternances sémantiques et pragmatiques peuvent être saisies. Ces résultats sont discutés dans le cadre de la théorie du Lexique Génératif (LG) de James Pustejovsky. L'article se conclut sur certaines propositions concrètes pour améliorer la relation et la coopération mutuelle entre linguistes et traducteurs.

\section{ABSTRACT}

This article investigates a topic at the intersection of translation studies, lexical semantics and corpus linguistics. Its general aim is to show how translation studies can benefit from both lexical semantics and corpus linguistics. The specific objective is to capture the semantic and pragmatic behavior of the noun destruction and its different translations into Arabic. The data are obtained from an English-Arabic parallel corpus made from UN texts and their translations (EAPCOUNT). The analysis of the data shows the polysemy of the word destruction as a number of semantic and pragmatic alternations can be captured. These findings are discussed in the frame of the Generative Lexicon (GL) theory developed by James Pustejovsky. The paper concludes with some concrete suggestions on how to enhance the relationship between linguists and translators and their mutual cooperation.

\section{MOTS-CLÉS/KEYWORDS}

traductologie fondée sur corpus, linguistique de corpus, sémantique lexicale, ambiguïté lexicale, polysémie

corpus-based translation studies, corpus linguistics, lexical semantics, lexical ambiguity, polysemy

It is my belief that the time is now ripe for a major redefinition of the scope and aims of translation studies, and that we are about to witness a turning point in the history of the discipline. I would like to argue that this turning point will come as a direct consequence of access to large corpora of both original and translated texts, and of development of specific methods and tools for interrogating such corpora in ways which are appropriate to the needs of translation scholars.

(Baker 1993: 235) 
Over the history of both linguistics and translation studies, the relationship between linguists and translators had been plagued by reciprocal disparagement in spite of the fact that there exists many areas of common interest. Malmkjær (1998: 535) is right when she asserts that "linguists and translators ought to be the best of friends; their areas of interest, however one wants to look at them, and however they may differ, have language and linguistic activity at the centre." Mutual cooperation can undoubtedly bring many advantages to both linguistic research and translation studies. It can even be argued that the area at the intersection of the two disciplines is wide enough to make such cooperation a necessity.

One of the major achievements of linguistic research has come from the development of corpus linguistics, and corpus semantics in particular (Stubbs 2001), as a method allowing large-scale, systematic and empirical studies to be performed. These studies are now possible thanks to the copious amounts of data that large corpora can make available. Related computational tools, such as concordancers and alignment tools are also an offshoot of this "new paradigm" (Laviosa 1998), which marked a new massive collaboration mood generated by globalization. Now it is largely accepted that computers have paved the way to more reliable methods in the study of language and, owing to computational tools, linguistic research has reached an interesting turning point (Pustejovsky 1995:5). Corpus linguists, for instance, extol the use of computers in linguistic research and equate them with telescopes and microscopes (Kenny 2001), where in the past data were "limited to what a single individual could experience and remember" (Sinclair 1991:1). The ever increasing number of lexical databases and the increasing availability of both original and translated texts in digital format have made such data all the more accessible and have enabled the construction of all kinds of corpora, including parallel corpora see, for example, Kenny $(2001 ; 2009)$ and Laviosa (1997) who present a clear typology of corpora.

A parallel corpus consists of original texts alongside their translation into another language. The advantages of using parallel (or translation) corpora in both translation studies and linguistics have become apparent and the corpus-based approach has become one of the most fashionable trends in both disciplines (Zanettin 2002; Salhi 2010). Since the beginning of the 1990s, corpus-based work has given rise to a "paradigm shift" in the ways through which language can be investigated and translation process can be conceptualized (Laviosa 1998) thanks to the work carried out by such pioneers in corpus linguistics as Sinclair (1991; 1998; 1999), and Church and Hanks (1990), scholars who introduced the corpus approach to translation studies like Baker (1993; 1996; 1998; 2003), and other researchers who followed her lead such as Kenny (2001), Laviosa (2002), Zanettin (2000; 2009) and Zanettin, Bernardini et al. (2003), to name but a few. Baker (1993) explains that corpus work in translation is motivated by the need to explore large amounts of texts after the decline of the semantic view in favor of the pragmatic view. In fact parallel corpora are often used to reveal translation solutions in the target language.

Parallel corpora, however, include, alongside translated texts, original ones. Yet, it is surprising that research in this new trend has focused almost exclusively on the investigation of translated text. There is a scarcity of studies that use parallel corpora to provide fresh insights into original texts (Salhi 2005). Not only do parallel corpora enable translation scholars to unveil the nature of translated texts (Laviosa 1998), but 
they may provide informations about the original language, which may be used to complement the work of linguists. But though mindful of the fact that any attempt to apply the parallel corpus approach to investigate the properties of lexical items in original text rather than in translated text is bound to raise questions about the feasibility of the exercise itself, we argue here that it might show how translation can inform linguistic research. We therefore investigate the noun destruction as a case study in order to demonstrate practically how the thesis is tenable.

We note that the description of nouns like destruction may vary from one dictionary to another and that it may sometimes appear as if it were monosemic. The lack of contexts of usage does not help the translators. We will see how knowledge of the semantic and pragmatic behavior of destruction is better informed when the item is looked at in real contexts and through its different translations into another language like Arabic. The data are taken from an English-Arabic Parallel Corpus of United Nations Texts (henceforth EAPCOUNT). This corpus, which will be described in detail below, contains texts and translations that can be regarded as reliable-an important consideration in an era when the reliability of texts is not always selfevident, especially when it comes to online texts and translations.

Through EAPCOUNT data, we hope to address the main question of the present article, namely how parallel corpora can come to the rescue of linguists and translation scholars alike in their investigation of the semantics, and pragmatics, of source language (SL) words. We also hope to achieve the broad aim of this article, which is to attempt to "endear" linguists to the world of translators and translation studies and vice versa. In order to try to achieve these goals the article is divided into six sections tackling the main aspects of the question. Section one shows how the gap between translation theory and translation practice is being bridged with the use of parallel corpora. Section two is devoted to the approach to lexical ambiguity and complementary polysemy taken from a translational perspective. Section three outlines how the item destruction has been handled in bilingual and monolingual dictionaries. Section four describes the methodology adopted when using EAPCOUNT data to account for the item destruction. Section five attempts to reveal the semantic and pragmatic behavior of destruction in EAPCOUNT. In section six a brief illustration is provided of how the findings of this paper are in line with the Generative Lexicon (GL) theory developed by the semanticist and generativist James Pustejovsky.

Before moving to the first section, a brief word is said here about the presentation of data in the current paper: Arabic-English and English-Arabic data are presented in the examples below as they appear in the fragments excerpted from EAPCOUNT. The data generally support discussion of contextually determined aspects of interpretation. However, morphemic glossing (left to right) is supplied where appropriate to facilitate analysis of selected features of the Arabic text. IPA phonological transcription for Arabic is provided when required by the context and is accompanied by a literal back translation of Arabic examples. Diacritics indicating emphatics and long vowels are therefore sometimes displayed.

\section{Parallel corpora, translation theory and translation practice}

The introduction of the corpus approach into translation studies can be seen as a response to, and a recovery from, the shortcomings of the previous linguistically- 
oriented approaches to translation (see Snell-Hornby 1988). The principal contribution of this approach lies in its concern with the systematic study of authentic examples of language in use as opposed to older approaches, which were concerned with language as a 'static' mental construct. Carter (1998: 80) argues that if one wants to analyse lexical items in discourse, one should "move beyond constructed examples to a consideration of real texts." Carter is obviously in favor of an approach to lexical items that deals with contextually defined units of meaning, a method which John Sinclair (1991) considers central to the understanding language. But Baker (1993: 237) argues that studies that take the context into account and "attempt to investigate usage, are, by definition, only feasible if access is available to real data, and, in the case of usage, to substantial amounts of it." She goes even further to argue that corpus work has emerged as a response to that need. On the other hand, it should also be pointed out that the emergence of the corpus approach has also been motivated by the purposes of applied linguistics.

Translation is now regarded as an act of communication rather than a mere linguistic exercise. Therefore we strongly believe that translation theory is coming to be used to mean the body of knowledge that we have about the process of translating, including the decisions and strategies that translators can adopt to solve the many translation problems they encounter. Indeed developments which are taking place in the world of theoretical studies owe much of their strengths to practice. In many instances corpus-based studies have helped bridge the gap between theory and practice as well as the academic and professional gap (see Salhi 2010), which have plagued translation for a long time as outlined earlier. Parallel corpora, for instance, have already been used as repertories of strategies deployed by on the past by translators, as well as repertories of translation translations (Zanettin 2002). The high demand for, and the large-scale use of, parallel corpora can be explained by the need to address questions related to equivalence at lexical level (see Baker 1992) on the basis of pragmatic meaning or word usages, rather than on the basis of prototypical meanings of words. The satisfaction of such demand would be practically impossible without computers and copious amounts of data such as those which may be elicited from parallel corpora. When updated, such corpora can help researchers keep pace with current real usages of words better than any regularly updated dictionary. Parallel corpora can provide information that neither bilingual nor monolingual dictionaries usually contain. The use of corpora can give trainee translators a higher degree of confidence, for they are enlightened with the examples offered by real-life translations and the wide range of strategies adopted in a specific genre, register or style (Salhi 2010). Finding appropriate translations for words having more than one meaning, without necessarily being contrastively ambiguous, can be presented as a vexing problem for trainee translators as, most of the time, they translate core meanings rather than the actual pragmatic meaning in the given context.

\section{Investigating lexical ambiguity from a translational perspective}

Investigating lexical ambiguity in a bilingual context is a complicated but informative and useful exercise. Such complexity is due to the fact that the semantic space is divided up by languages quite differently and that complete and stable equivalences are rare. 


\subsection{Lexical ambiguity, homonymy and polysemy}

It is almost certain that the majority of words in language carry more than one meaning, a phenomenon traditionally known as lexical ambiguity. Lexical ambiguity is an inherent problem of language because humans are impelled to assign to a finite resource of meaningful items an unlimited set of applications (Pustejovsky 1995; Sinclair 1998). According to Pustejovsky (1995: 27), Weinreich (1964) distinguishes two types of lexical ambiguity. The first type is that of contrastive ambiguity where, synchronically speaking, there is no relation between the different meanings of a word, i.e. cases of homonymy: in fact, this means that homonyms are actually independant lexical units. Well-known examples provided by Pustejovsky (1995: 27) are the cases of bank as in Mary walked along the bank of the river, vs. HarborBank is the richest bank in the city, or taxi, line, bar. ${ }^{1}$ In dictionaries, a word exhibiting two distinct meanings as such would have two distinct entries bank1 and bank2 or line1 and line2 and so on. Pustejovsky $(1991,1995)$ calls a lexicon of this kind a sense enumerative lexicon, which he criticizes for undermining the richness of the knowledge that lexical items contain.

The second type of lexical ambiguity is what Pustejovsky calls complementary polysemy $(\mathrm{CP})$, which applies where a word carries two (or more) meanings that relate to a common basic (or core) meaning. As for bank, compare the bank raised its interest rates yesterday, the store is next to the newly constructed bank and the bank appeared first in Italy in the renaissance (Pustejovsky 1995: 28). It is interesting to note that contrastive polysemy is essentially a pragmatically-constrained ambiguity that requires knowledge of the situational context to be resolved. For instance, in a sentence like we finally reached the bank, only the context of situation can tell us which bank is pointed to here, the financial institution or the edge of a river (see Stubbs 2001: 14 for more details on the ambiguity of the item bank). The complexity arising from a case of CP, on the other hand, is that it often cannot be disambiguated unless both semantic knowledge and pragmatic information are combined and made to complement each other. Pustejovsky calls these two concepts lexical knowledge and commonsense knowledge respectively. Thus the polysemous meanings in this case are in effect the different usages of lexical items in context.

\subsection{Prototypical meaning vs. word usage and translation}

According to Pustejovsky (1995), the problem of lexical ambiguity and polysemy is very central to language. This means that if you take any item in the way bank, window and university are handled above, you will find out that it exhibits at least two different senses, one of which is a core or prototypical meaning and the other is contextual. The various dimensions of lexical meaning are too complex to allow an easy answer (Stubbs 2001), but for the sake of simplicity, we will consider a word sense as either prototypical or contextual, though the contextual meaning overlaps sometimes to a great extent with the prototypical one.

A prototypical meaning is the meaning being immediately recalled in the memory when a word is uttered in isolation from any context, although some variations may be observed among speakers (Rosch 1973). Prototypical meanings of words constitute most of the time only a preliminary stage in the constitution of the final 
contextual meaning which can never be expressed or perceived out of context. In some cases the prototypical meaning is hardly found through the final usage of a given word. There is no doubt that people rarely communicate only with core meanings of words. Communication depends heavily on contextual, pragmatic, meanings that words may convey through their lexical environment (Firth 1957) and the situational context. Therefore, meaning, as such, does not consist of something stable and pre-existing that can be elicited from texts in one language and rendered in texts of another language in the same way as one may copy a text from one file to another, as if translation were a copy and paste exercise and the translator a processing tool (Baker 1993: 236). Equivalence in word meaning is closely linked with correspondence in word usage, which goes beyond its prototypical meaning(s). This is a prerequisite for understanding texts and utterances and, therefore, for translating. Inferring pragmatic meanings of items is not, however, always easy and straightforward, especially when it comes to written texts whose authors are rarely accessible when more information about their intentions and implicatures is sought.

Inferences are especially problematic for novice translators who, when frustrated by the challenging and demanding translation task, fall back on monolingual and bilingual dictionaries which provide nothing more than brief definitions or prototypical equivalents (Salhi 2012). Therefore they tend to attach more importance to core meanings than the latter really merit. The inherent shortcomings of bilingual dictionaries come from the fact that they suggest translations on the basis of more or less prototypical meanings of SL items and potential usages of target language [TL] items, while the strength of parallel corpora is that they offer translations on the basis of actual usages of words following an approach which handles language as a dynamic mental construct (Carter 1998). While bilingual dictionaries tend to concentrate on the most obvious and prototypical and translations, parallel corpora offer researchers and translators a wider and richer set of real translations, reflecting context-bound decisions and strategies of professional translators. They can thus be used in the processes of teaching and learning translation, in that they encourage students to think of a wider range of possible translations that go way beyond what strictly theoretical linguistics or lexicography could offer them. Full reliance on sources of lexical data such as monolingual and bilingual dictionaries may therefore impact their translational competence and may result in non-fluent TL output. Another advantage of parallel corpora, and translations in general, is that they can be used to explore SL items through TL translations, an exercise which is less probable using dictionaries.

\subsection{Using parallel corpora to rediscover the source text}

Although parallel corpora are now widely used to investigate translated texts through techniques based on comparisons with the original texts, as already mentioned, they are less often used to study the original. It is true that any translation is bound to its original, but once a translation is final, it becomes a fully-fledged language unit and a text in its own right (Baker 1993) as long as the rules of the TL and principles of coherence and cohesion are respected, though there is much controversy about the degree of equivalence which may be reached. It is not argued here that a translation should reach the status of the original-a translation remains always a translation 
with its own specific features-but instead the aim is to draw attention to the service a translation may give to a researcher in investigating an original text or discourse.

\section{Destruction in monolingual and bilingual dictionaries}

Before moving on the use of EAPCOUNT as to explore the behavior of the word destruction, we how this item has been handled in bilingual and monolingual dictionaries.

\subsection{Destruction in English-Arabic dictionaries}

A wide variety of English-Arabic dictionaries, either printed or electronic (online), suggest some translation solutions without any further information about the possible context of usage, which can be quite confusing sometimes. This is the case for the noun destruction. LingvoSoft online Dictionary and Sakhr online Dictionary (Table 1) are some representative samples of what electronic English-Arabic bilingual dictionaries generally tend to offer. They present nothing more than a list of decontextualized equivalents, without any information on their possible usages. They also reflect a general failure to utilize frequency information as a criteria for deterاجتياح mining the order of the different meanings of polysemous words. Having (literally invasion) set as the fourth equivalent of destruction in the Sakhr Dictionary, while دمار (literally, [devastation/state of destruction]) is listed as the $17^{\text {th }}$ equivalent is a good example of the somehow anarchical state of this kind of dictionary. In fact, the equivalents are just listed randomly, without any serious attempt to categorize them in accordance with some specific criterion. What is even worse is that some of the proposed equivalents are items which are less likely to be any translation of destruction, such as محب الهدم (literally, [genocide]) محبادة (literally, [demolition lover]).

TABLE 1

Destruction in some online English-Arabic dictionaries

\begin{tabular}{|c|c|c|}
\hline 1 & $\begin{array}{l}\text { LingvoSoft } \\
\text { dictionary }\end{array}$ & 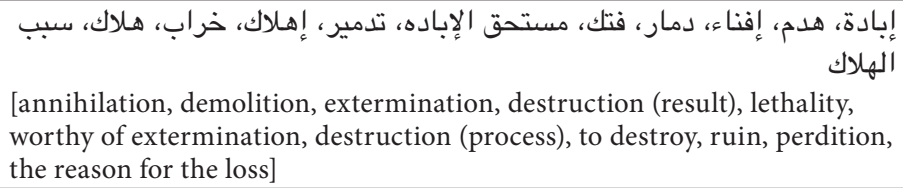 \\
\hline 2 & $\begin{array}{l}\text { Sakhr online } \\
\text { Dictionary }\end{array}$ & 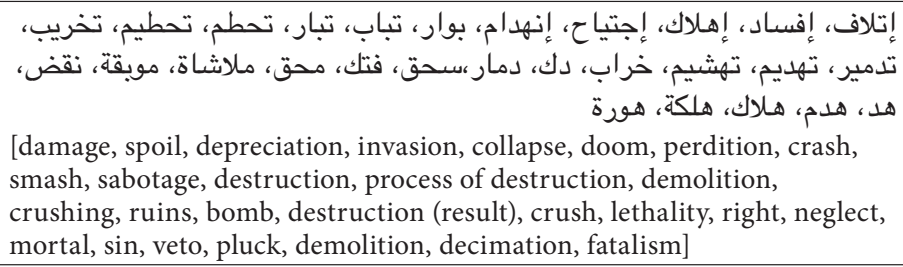 \\
\hline 3 & Ectaco $U K^{4}$ & 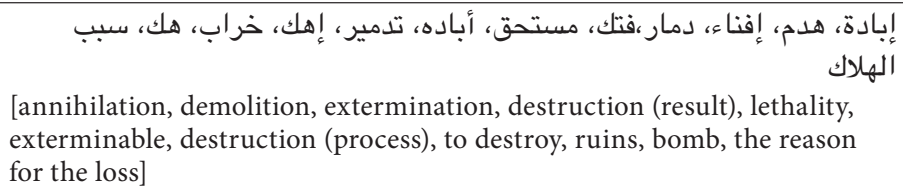 \\
\hline
\end{tabular}


Another limitation of English-Arabic bilingual dictionaries is the lack of illustrative examples. Most of them are likely to suffer such weakness, though larger and more thorough dictionaries may be less prone to these charges. But even printed bilingual dictionaries lack the necessary contextual information (CI). Table 2 shows the entry for destruction in the Al-Mawrid English-Arabic Dictionary (2005), one of the most comprehensive and reliable dictionaries for this language pair.

TABLE 2

Destruction in the Al-Mawrid English-Arabic Dictionary5

\begin{tabular}{|c|c|c|c|}
\hline 1. & تذام & $\begin{array}{l}\text { demolition, tearing down } \\
\text { destroying } \\
\text { devastation, ravage } \\
\text { ruining, annihilation } \\
\text { genocide } \\
\text { etc. }\end{array}$ & ACT or PROCESS of destruction \\
\hline 2. & دراب & $\begin{array}{l}\text { devastation, ruin } \\
\text { ravage, wreck } \\
\text { wreckage, doom, perdition } \\
\text { etc. }\end{array}$ & STATE of being destroyed \\
\hline 3. & قالهلكة او مدمرة & $\begin{array}{l}\text { Alcohol is likely to be his (cause of) } \\
\text { destruction }\end{array}$ & CAUSE of destruction \\
\hline
\end{tabular}

What is interesting about this account of destruction is that equivalents have been classified into three sense-based categories. The first set, which refer to the act of destroying, is kept separate from the second set where destruction refers to a state. In the third set, the equivalents denote the cause of destruction, more precisely a destroying agency. The authors of the dictionary provided an example probably because they felt that this sense might be confusing. Although better than the randomly set equivalents in the English-Arabic e-dictionaries cited above, such a treatment is still very reductive, and translations are generally not examplified. If they were to rely fully on such dictionaries, trainee translators would face clear challenges in translating less typical usages of destruction like in Examples (1a) and (1b).

(1) a. the destruction of wheat crops

محاصيل الحبوب

[cereal crops??]

b. the destruction of rights and freedoms

الحقوق والحريات

[freedom and rights??]

None of the equivalents found in the bilingual dictionaries would faithfully express the meaning of destruction when collocating with wheat crops or human rights. Thus, while bilingual dictionaries are useful for delivering quick references for trainee translators, this same asset may be their main weakness, as they can deliver non-fluent and hasty translations instead. 


\subsection{Destruction in English Monolingual Dictionaries}

While the majority of bilingual dictionaries are criticized for providing no more than proposed equivalents, monolingual dictionaries may also be criticized for undermining the real richness of the semantic and pragmatic knowledge that can be elicited from polysemous lexical items. Table 3 shows a sample of definitions for destruction reproduced from often-cited English dictionaries, the Oxford Advanced Learner's Dictionary (online), the Cambridge Advanced Learner's Dictionary (online), and the Oxford English Dictionary (1989; printed).

TABLE 3

\section{Destruction in some English monolingual dictionaries6}

\begin{tabular}{|c|c|c|}
\hline 1 & $\begin{array}{l}\text { Oxford Advanced } \\
\text { Learner's Dictionary }\end{array}$ & $\begin{array}{l}\text { [UNCOUNTABLE] } \\
\text { the act of destroying something; the process of being destroyed } \\
\text { - the destruction of the rainforests } \\
\text { - weapons of mass destruction } \\
\text { - a tidal wave bringing death and destruction in its wake } \\
\text { - The central argument is that capitalism sows the seeds of its own } \\
\text { destruction(= creates the forces that destroy it). }\end{array}$ \\
\hline 2 & $\begin{array}{l}\text { Cambridge Advanced } \\
\text { Learner's Dictionary } \\
\text { \& Thesaurus }\end{array}$ & $\begin{array}{l}\text { noun } \\
\text { the act of destroying something, or the fact of being destroyed: } \\
\text { Many people are very concerned about the destruction of the } \\
\text { rainforests. } \\
\text { Unusually high winds left a trail of destruction over the area. } \\
\text { weapons of mass destruction (= those which kill or hurt large numbers } \\
\text { of people) }\end{array}$ \\
\hline 3 & $\begin{array}{l}\text { Oxford English } \\
\text { Dictionary }\end{array}$ & $\begin{array}{l}\text { 1) The action of demolishing a building or structure of any kind, of } \\
\text { a) pulling to pieces, reducing to fragments, undoing, wasting, } \\
\text { rendering useless, putting an end to, or doing away with } \\
\text { anything material or immaterial; demolition. } \\
\text { b) The action of ravaging or laying waste; havoc, ruin. } \\
\text { c) The action of putting to death, slaughter, now chiefly said of } \\
\text { multitudes of men or animals, and of noxious creatures. } \\
\text { 2) The fact, condition, or state of being destroyed, ruin. } \\
\text { 3) A cause or means of destruction }\end{array}$ \\
\hline
\end{tabular}

The first two monolingual dictionaries in Table 3 provide some illustrative examples where destruction is used in potential contexts. However, they tend to limit their range of focus to the most prototypical senses, and in a similar way. This might reflect the fact that the latest editions of these dictionaries are taking advantage of the availability of huge corpus resources, so as to best reflect current English. These dictionaries, however, still cannot be exhaustive by any means. Most of them fall short of offering examples which can go far beyond the scope of prototypical meanings.

Other monolingual dictionaries, such as the third one in Table 3 (Oxford English Dictionary 1989), are more comprehensive in their description of destruction but still are doomed to go amiss when attempting to reflect the real richness of the lexical item as well as when trying to keep pace with its semantic development and dynamism. In addition, because the item belongs to a general register with some technical and legal uses in certain contexts, these dictionaries, due to size constraints, provide nothing more than a general definition fitting a wide range of contexts. 
In the above definitions, there is too much emphasis on prototypical senses of the item. Buildings are among the objects most prototypically associated with the act of destruction and they are presented either explicitly or implicitly throughout the whole description. This same concern is raised by Pustejovsky who deplores current monolingual dictionaries for their reductionist approach to meaning. Current dictionaries, according to him, reflect a particularly static approach in their handling of the concept of context by enforcing certain readings of a word instead of others. He argues that "the numbers of and distinctions between senses within an entry are 'frozen' into a fixed grammar's lexicon. Furthermore, definitions hardly make any provisions for the notion that boundaries between word senses may shift with context" (Pustejovsky 1993a: 73). This state of affairs strongly suggests that a corpusbased approach is highly appropriate in a translation training environment, especially when complexities are generated by this systematic ambiguity.

\section{Methodology}

This section describes the main features of EAPCOUNT corpus, gives a brief overview of the methodology adopted for its development and describes the procedures used to analyse and interpret its data.

\subsection{Description of EAPCOUNT}

EAPCOUNT, as used in the research presented here, ${ }^{10}$ comprised 261 English-Arabic bitexts aligned on a paragraph basis. The English subcorpus contained 2,749,876 word tokens, with 75,606 word types. The Arabic translation subcorpus had a slightly fewer number of word tokens $(2,642,615)$, yet differed greatly in terms of th word types, which is 122,154 . The whole corpus contained 5,392,491 tokens.

EAPCOUNT consists mainly, but not exclusively, of resolutions and annual reports issued by different UN organizations and institutions. Some texts are taken from the authoritative publications of another UN-like institution, namely the InterParliamentary Union (IPU), representing $2.18 \%$ of the total number of tokens in the English subcorpus. But the great majority of texts are issued by the General Assembly and Security Council (66.44\% SL tokens). The assumption here is that TL texts produced by these selected international bodies can be considered as translations of a high degree of reliability. All texts have been downloaded from first-hand sources (official websites of these agencies) in order to make sure that the publications are all kept in their original form. Table 4 shows the sources of the texts as well as the number of texts and tokens in the English subcorpus. ${ }^{11}$ 
TABLE 4

Number of texts and word tokens of the English Subcorpus per organization

\begin{tabular}{|l|l|c|c|c|c|}
\hline Source & $\begin{array}{c}\text { Number of } \\
\text { texts }\end{array}$ & Percentage & $\begin{array}{c}\text { Number of } \\
\text { tokens }\end{array}$ & Percentage \\
\hline \multirow{5}{*}{} & $\begin{array}{l}\text { General Assembly and Security } \\
\text { Council }\end{array}$ & 185 & $70.88 \%$ & $1,660,875$ & $66.44 \%$ \\
\cline { 2 - 6 } & UNICEF & 8 & $3.06 \%$ & 47,419 & $1.72 \%$ \\
\cline { 2 - 6 } & UNIDO & 4 & $1.5 \%$ & 150,570 & $5.47 \%$ \\
\cline { 2 - 6 } $\begin{array}{l}\text { United } \\
\text { Nations } \\
\text { Agencies }\end{array}$ & UN Office for Outer Space Affairs & 3 & $1.14 \%$ & 38,381 & $1.39 \%$ \\
\cline { 2 - 6 } & UNESCO & 1 & $0.38 \%$ & 19,564 & $0.71 \%$ \\
\cline { 2 - 6 } & Economic and Social Council & 11 & $4.21 \%$ & 22,077 & $0.80 \%$ \\
\cline { 2 - 6 } & IMF & 1 & $0.38 \%$ & 83,349 & $3.03 \%$ \\
\cline { 2 - 6 } & Others & 12 & $2.29 \%$ & 483,638 & $17.58 \%$ \\
\hline $\begin{array}{l}\text { Non-UN } \\
\text { Agencies }\end{array}$ & IPU & 30 & $11.49 \%$ & 60,206 & $2.18 \%$ \\
\hline Total & & 261 & $100 \%$ & $2,749,876$ & $100 \%$ \\
\hline
\end{tabular}

EAPCOUNT covers a time-frame of about 14 years (Table 5) and may be considered to be synchronic, even though Meyer (2002:46) maintains that "a time-frame of 5 to 10 years seems reasonable" for a corpus to be synchronic. We argue that almost all original texts as well as the translations are issued by the same bodies and are governed by strict norms and standards of writing and translation, which may likely mean that language change happens at a slower pace. In addition, $22.6 \%$ of the texts were produced in $2009,16 \%$ in 2007 , and $13.4 \%$ in 2005 , while $93.87 \%$ of the texts were produced over a period of 9 years, namely from 2001 to 2009, i.e. within the reasonable time-frame set by Meyer.

TABLE 5

The time-frame of EAPCOUNT texts

\begin{tabular}{|l|c|c|c|c|c|c|c|c|c|c|c|c|c|c|}
\hline Years & 96 & 97 & 98 & 99 & 00 & 01 & 02 & 03 & 04 & 05 & 06 & 07 & 08 & 09 \\
\hline $\begin{array}{l}\text { Number } \\
\text { of texts }\end{array}$ & 1 & 1 & 2 & 5 & 7 & 13 & 5 & 14 & 24 & 35 & 31 & 42 & 22 & 59 \\
\hline
\end{tabular}

\subsection{Compiling EAPCOUNT}

The compilation and alignment of EAPCOUNT involved several steps. First, the texts were cleaned up and extra material like pictures, tables, footnotes, and other untranslated parts were removed. Segmentation was then carried out manually at the level of paragraphs, with respect to the original texts, and Arabic translations were divided accordingly. We made sure that all the paragraphs could stand by themselves as meaningful complete units. Because we did not have at our disposal any alignment software that would work with Arabic scripts, the texts were manually aligned in a single file containing the English paragraphs and their Arabic counterparts in alternance. After completing this process, EAPCOUNT was ready for use.

\subsection{Software and method used to analyze EAPCOUNT data}

We used a concordance software, AntConc3.2.1w, ${ }^{12}$ which provides a general purpose tool for conducting a wide range of investigations of copious amount of linguistic 
data (Anthony 2006). It was used in the process of retrieval of the occurrences of destruction and its Arabic translations.

The method consisted in four main steps. We first retrieved the occurrences of the word destruction in the English subcorpus (133 occurrences). We then eliminated all the concordance lines that were similar: for example, the phrase weapons of mass destruction is always translated as أسلحة الدمار الثامل.

Then we isolated the Arabic translations for destruction. We then searched all the Arabic contexts containing an occurrence of these translations, as to find out if they were used to translate some other English lexical units.

The third step consisted in investigating the collocations of destruction, as to provide a significant insight into the behavior of this word. In other words, we categorized the occurrences the word destruction in their respective contexts to examine the word's English collocational behavior based on the different Arabic translations.

The final step consisted in the capture of the regularities of destruction use and perception. In the following section, we move on to look at how some bilingual and monolingual dictionaries deal with the entry destruction to be able to draw some conclusions based on a comparisons between such dictionaries and EAPCOUNT.

\section{Investigating the semantic and pragmatic behavior of destruction in EAPCOUNT}

\subsection{Occurrences of destruction in EAPCOUNT}

The concordancer AntConc 3.2.1w found 133 instances of the noun destruction in EAPCOUNT (See Table 6 for the ten first contexts). Four different translations are found for destruction in the corpus, namely damār (دمار), tadmīr (تدمير), taqwid ) (تقويض) and itläf (إتلاف).

\section{TABLE 6}

\section{The ten first instances of destruction in EAPCOUNT}

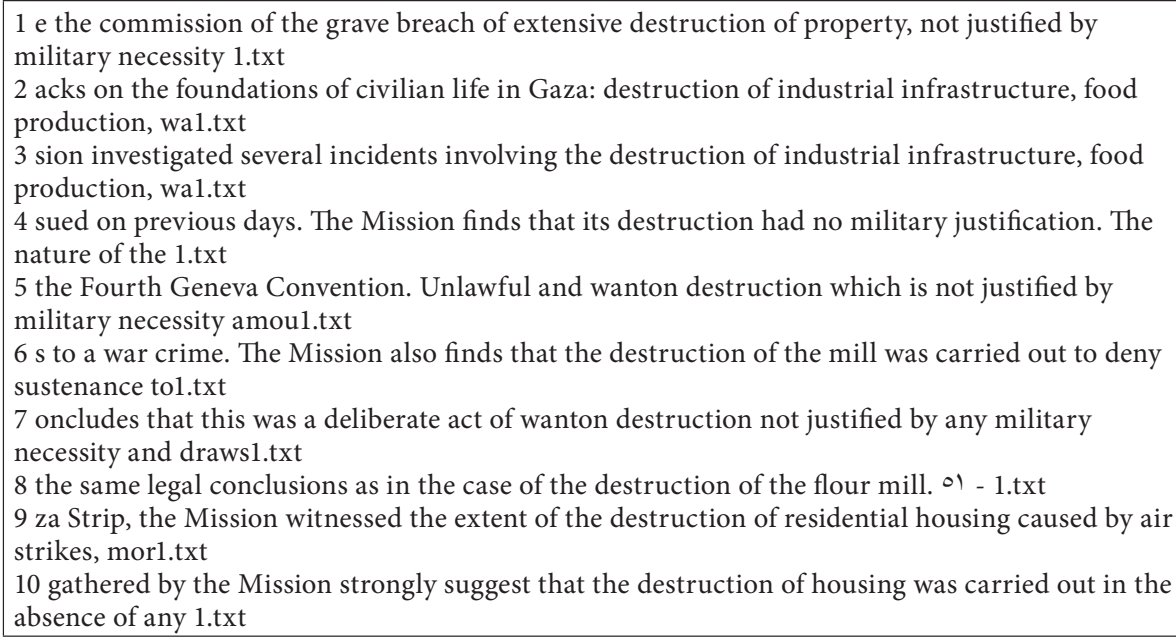




\subsection{Occurrences of target words}

\subsubsection{Case of تدمير [tadmìr]}

This target word has 75 occurrences. The overwhelming majority of these occurrences (70 instances) are the translations of destruction while devastation (2), demolition (2; Example [2]) and damage (1) account for the rest.

$$
\text { و قد جرى بنجاح تدمير 5,529 جهازا متفجرا في موقع تجمع الجيش الماوي في شتوان. }
$$

[wa qad zarā bi-nazāhin tadmīru 5,529 zihāzan mutafaziran fi mawqi?`i tazamu? al-zaj [ al-māwi fi Jitwān]

The demolition of 5,529 explosive items was successfully carried out at the Maoist cantonment site in Chitwan.

\subsubsection{Case of دمار [damār]}

This target word has 45 occurrences, 37 of which are translations of destruction. Seventeen (17) of these occurrences are the translations of destruction in the expression weapons of mass destruction. The other eight occurrences are the translations of devastation (5; Example [3]), damage (2) and havoc (1).

$$
\text { و في الإنتعاش من الدمار الذي سبيه عقدان من الحرب. }
$$

[wa fi al-intiৎāêi mina ad-damār alaði sababahou Yaqd-āni mina al-harb]

[and in the recovery from the destruction that caused-it decade-dual from the war] recovering from the devastation caused by over two decades of war

\subsubsection{Case of تقويض [taqwids]}

The third word occurs 31 times, with only 1 occurrence being a translation of destruction. The other occurrences comprise 25 translations of to undermine (Example [5]), 2 translations of erosion, 1 translation of to compromise and 1 translation of to unravel (Example [6]).

(4)

$$
\text { قد نجحت في تقويض التحالفات المثيرة للقلق. }
$$

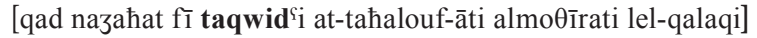

[emphasis- succeeded in undermining the allying-pl the arising to worry]

It had successfully undermined the recent worrying alliances.

$$
\text { سيعرض عملية وقف إطلاق النار الهثة لخطر التقويض. }
$$

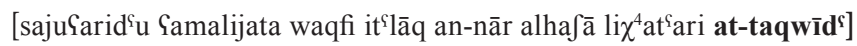

[will expose process cease shooting the fire the fragile to danger the undermining] The fragile ceasefire would start to unravel

\subsubsection{Case of إتلاف [itläf]}

This fourth word occurs 5 times. Only 1 occurrence is a translation of destruction, 2occurrences are the translations of damage (Example [6]), 1 is a translation of annihilation and 1 is a translation of to vandalize.

[Itlāf markaba tābiৎa li-maktabi al-omam al-motahid-a] إتلاف مركبة تابعة لمكتب الامم المتحدة [ravaging vehicle belonging to office the nations the united-fem/pl] A BINUB vehicle was damaged 
These results provide an insight concerning the most prototypical usage of destruction in this, more or less, legal context. The polysemous sense ${ }^{13}$ expressed by the Arabic lexical item tadmir (تدمير) is more likely to correspond to the most prototypical usage of destruction in this context. This means that most usages of destruction have a semantic link with the sense which expresses the act of destroying. We must recall here that the repetitive instances of the expression weapons of mass destruction were weeded out from the analysis. For unlike other instances of collocations, which are all the result of much freer combinations - though they are still أسلحة الدمار الشامل habitual cooccurrences, this expression and its Arabic equivalent are rather frozen expressions, i.e. compound nouns. With such fixed expressions no variation is possible at all. The choice not to include them follows from the assumption that compounds should not be taken into account if we are to give an accurate proportional representation of the distribution of the different translations of destruction as found in the corpus.

The next step was to analyse the collocations where destruction appears and try to classify them according to the different translations proposed, in an attempt to understand why destruction is translated differently each time and with the aim of uncovering the underlying ambiguity of this lexical item in the SL.

\subsection{Collocations of destruction}

Firth, in a famous statement, argues that "you shall know a word by the company it keeps" (Firth 1957: 11). But despite the fact that there has been a great deal of theoretical and applied work related to collocations, there seems to be no agreed-upon definition for this concept (e.g. Allerton 1984; Cruse 1986; Sinclair 1991). Depending on their interests and points of view, researchers have focused on different aspects of collocations and given different definitions. One of the often-quoted definitions has been proposed by Sinclair: a collocation is "the occurrence of two or more words within a short space of each other in a text" (Sinclair 1991: 170). One obvious conclusion that can be drawn from this definition is the fact that the meaning of a word is, to a greater or lesser extent, inter-dependent with other words' meanings. Studying the collocations of an item like destruction corresponding to each Arabic translation may help us to grasp the extent of the polysemy of destruction, and to explore the specific meaning of the Arabic equivalents.

The translation of destruction by تدمير [tadmīr] occurs when it denotes an act by an animate agent who destroys something for either evil or good purposes (Example [7])

(7)

[tadmīr bąd' al-hajakil al-asāsi-ja]

[Destroying some the - structures the-base-fem/pl]

Destruction of basic infrastructure

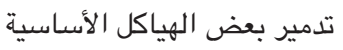

The word دمار [damār] is used to refer to the result or the final state of a destructive event or act either by an animate agent or by nature (Example [8]).

[ad-damār natizata al-mazāạa]

[the destruction due to the-famine]

the destruction caused by famine 
In the case of تقويض [taqwid'], what is meant is the destruction of non-concrete objects (abstract and moral objects) such as rights, freedom (Example [9]) or identity.

(9)

$$
\text { تقويض الحقوق و الحريات }
$$

[taqwīd ${ }^{\varsigma}$ al- huquq w al- horij-āt]

[undermining the-right and the-freedom-pl]

the destruction of rights and freedoms

Example [10] shows that when destruction is translated by إتلاف [itlāf], it is a case of partial and not complete demolition or devastation. This term is derived from the root أتلف [atlafa], which means to deteriorate, to corrode, or to puncture, etc.

[itlāf maћās`īl al- huboub]

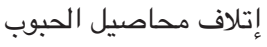

[Ravaging crops the wheat]

The destruction of wheat crops

These findings from EAPCOUNT clearly support Zanettin's (2002: 11) claim that "while dictionaries favour a synthetic approach to lexical meaning (via definitions) corpora offer an analytic approach (via multiple contexts)." While analyzing the behavior of destruction through (1) its collocates in English source texts, (2) its various translations in the Arabic target texts, and (3) the other English lexical items than destruction translated by these latter, we noticed that a number of systematic alternations of the meaning of destruction could be captured. Across EAPCOUNT, destruction is used in a systematic way that makes it possible to analyse the extent of its meaning according to a number of common behavioural traits.

\subsection{Contextual alternations found in EAPCOUNT}

\subsubsection{Negative or Positive Connotations}

Through its lexicographical descriptions, destruction is generally perceived to refer to a negative act, with pejorative or at best neutral accounts of its meaning (see upper sections). In EAPCOUNT, however, it may also present some positive connotation, for example, in contexts in which it corresponds to the destruction of harmful and/ or destructive objects. Example (11) comes from the report of the Secretary-General on the situation concerning Western Sahara in which he welcomes the efforts of the parties to clear the Territory of mines and unexploded ordonance, and goes on to express his pleasure with the notable humanitarian mine action progress achieved in this region.

(11) I commend the Royal Moroccan Army for its efforts in the destruction of hazardous explosive ordonance and highlight its request for more resources, such as mechanical and detection equipment, in order to increase the pace and efficiency of its clearance work.

Still we should admit that rating some acts as negative and even destructive and others as positive may be intuitive, subjective or even ideological, exactly like the variable rating of fruits or birds as more or less prototypical. However, we feel that the CI provided for each example helps the reader to grasp the peculiarities of each usage. 


\subsubsection{Extensive or Partial Act of Destruction Alternations}

Contexts found in EAPCOUNT reveal a number of situations where the act of destruction is either complete or partial. A context-dependent case of complete destruction becomes all the more obvious when considering the English original of the translated expression ' 'إتلاف بالكامل 'total devastation] as annihilation and not destruction (taken from a letter dated 29 December 2005 from the Permanent Representative of Italy to the United Nations addressed to the Secretary-General).

(12) With an adequate fund, too, the United Nations would be able to act quickly before an emergency - such as growing numbers of locusts in Africa - became a fullblown catastrophe, such as the annihilation of crops.

$$
\text { إتلاف المحاصيل الزراعية بكاملها }
$$

[Ittāf al-maћas $\varsigma^{\varsigma} \bar{l}$ aziraSija bi-kāmiliha] [ravaging the-crops agricultural completely]

In contrast, in Example (12) (taken from the $18^{\text {th }}$ Progress report of the SecretaryGeneral on the United Nations Mission in Liberia) إتلاف [devastation], is chosen as the translation of destruction. Therefore destruction when translated as ' إتلاف ' was meant to be partial rather than complete.

(13) Nuclear weapons of mass destruction can hit earth and destroy everything at a blink.

In Example (13), extensive destruction is clear without further contextual information.

\subsubsection{Concrete / Abstract Alternation}

Destruction is often associated with concrete objects, as is reflected in almost all monolingual and bilingual dictionaries, except the Oxford English Dictionary (1989) which states that destruction may be used when referring to immaterial objects (see Table 5). Material property, bridges, schools, farms, weapons, factories, and so on are all common prototypical objects of destruction. Destruction of abstract things, however, may not come to the mind immediately. Yet, findings from the empirical work using EAPCOUNT show that destruction of abstract objects such as identity, rights, freedoms, spirit, will, life and so on, is quite common and repetitive enough to catch our attention (see Example [10]).

\subsubsection{Deliberate (even Systematic)/ Natural (Non-Deliberate) Alternation}

Destruction is often taken as a deliberate action, but alternations found in EAPCOUNT indicate that it can be natural or accidental as well. Example (14) is taken from the report of the UN Secretary-General on the situation concerning Western Sahara, in which the Royal Moroccan Army has deliberatly destroyed anti-personnel mines and other unexploded ordnance under the control of the United Nations Mission for the Referendum in Western Sahara (MINURSO).

(14) MINURSO monitored the destruction by the Army of 70 anti-personnel mines, 62 anti-tank mines and 1,644 pieces of large-calibre unexploded ordnance, as well as of 1,500 mines and close to 10,000 items of other explosive ordnance from stockpiles. 
Destruction can also be accidental, as in the case of natural disasters. Example (15) is taken from IPU Document No 17 (113th IPU Assembly).

(15) Also distressed at the loss of life and destruction caused by famine and other natural disasters in parts of Africa.

\section{Discussion}

\subsection{Methodology}

The identification of regularities in the semantic properties of destruction is partially based on EAPCOUNT data, which is contextual in nature, supplemented by introspective interpretation. Another limitation is related to the alternations found in EAPCOUNT. Some of the classifications involve a sort of value judgements such as positive/negative or deliberate/natural. What may be seen as positive by some parties can be seen as negative by others, while what is deliberate or natural is not left to any interpretation. However, when a certain amount of subjectivity was at stake, the primary reference was the meaning and the connotation as they were expressed in the contexts under analyse - in another words, the intention of the author.

\subsection{Interpretation of the data on the frame the Generative Lexicon (GL) theory}

The results obtained in this article are in line with the GL theory developed by the formal semanticist James Pustejovsky (1995), especially when it comes to the extent to which the real richness of the lexical knowledge is mirrored in both representations. First, Pustejovsky proposed meaning alternations as to illustrate the concept of complementary polysemy, such as the Producer/Product alternation for the lexical item newspaper: The newspaper fired its editor, vs. John spilled coffee on the newspaper (Pustejovsky 1995: 31). This is reminiscent of the meaning alternations observed in the case of destruction.

The ambiguous behavior of destruction may also be described through the concept of coercion, which is defined by Pustejovsky (1995) and Pustejovsky and Jezek (2008) as a semantic operation which compels an argument to denote a required meaning through a head lexical item. Pustejovsky claims that some sense variation can be captured through a mechanism which makes a shift in the semantic meaning of an entity. Coercion, for instance, explains how a fast car is one that can be driven quickly, while a fast typist is one who can type quickly. By the same token, a good pilot will be someone who is "good at navigating air vessels," while a good knife is a knife that "cuts well" (Fillmore 1969:123). Likewise, this same mechanism can also explain how 'the destruction of villages' will be an act of ravaging buildings, while 'the destruction of rights' is the violation of rights, 'the destruction of water catchment areas' is the natural end of these areas, and 'the destruction of wheat crops' is only a partial kind of devastation or deterioration and so forth. Therefore, in order to investigate coercion phenomena, corpora can be very useful as a source of data. Corpora can help us to conduct research on how words are actually used as opposed to the way they should be used. These results can never be achieved if we relied solely on dictionaries, or they would have to be completely exhaustive. Being so, we can briefly list the following advantages of parallel corpora over dictionaries. First, while dictionaries are intended to provide the user with the general prototypical meanings 
of headwords, parallel corpora provide more reliable and up to date prototypical meanings in specific knowledge domains. Second, parallel corpora are of valuable help to translators and linguists alike and can help bridge the gap between linguists and translation theorists. Finally, this type of analysis may be carried out with any kind of language pair, subject area or corpora.

\section{Concluding remarks and suggestions}

In this article we have attempted to demonstrate how translation (or parallel) corpora come to the rescue of linguists in their semantic and pragmatic investigations of lexical items. In particular, we have tried to show how EAPCOUNT can reveal the ambiguous behavior of the noun destruction through its different translations into Arabic. Our data show that such behavior is too complex and fuzzy to accept an account from one perspective, within one language, by one researcher and restricted to one field of study. For instance it is found that there should be no clear-cut distinction between questions of polysemy, synonymy and collocations and analyses of the semantics of words and pragmatics of words, which are so much overlapping that they seem to be just different sides of the same coin. No researcher can conduct a serious empirical investigation of one phenomenon without seeking information from the other. This state of affairs makes it necessary to seek better cooperation between linguists, on the one hand, and translators and translation scholars on the other. It is high time that translators, translation theorists, translation teachers and linguists became the best of friends, no longer endorsing traditional conflicting views, and eased the reciprocal tension that has plagued linguistic and translation research in the history of both fields of enquiry.

Interestingly, the findings of this study prompt me to make some suggestions on how to enhance such cooperation among linguists, professional translators, translation teachers and trainee translators. (1) Linguists, for instance, are called upon to review their views about translation and translation studies. Translation can now be appraised as a fruitful exercise and thanks to corpora it can be re-associated with the excitement of new discoveries. (2) Professional translators are called upon to make their translations available to novice translators, linguists, and translation theorists. (3) Translation teachers are called upon to introduce recent linguistic approaches and technology in the translation classroom. (4) As for translation students, they are called upon to invest some time and effort in collecting their own corpora, to protect their translation products from inappropriate prototypical or dictionary meanings, and to dispel the misconceptions that still exist about one-to-one equivalence across languages. Therefore, the current study has shown a case where cooperation from all concerned parties is needed, whether they are students, teachers, researchers, domain experts, terminologists, linguists, translators or writers of various text types, in order not to reinvent the wheel (Salhi 2010).

\section{NOTES}

1. See also Pustejovsky (1995: 27):

First we leave the gate, then we taxi down, vs. John saw the taxi down the street.

Drop me a line when you are in Boston, vs. We built a fence along the property line.

The judge asked the defendant to approach the bar, vs. the defendant was in the pub at the bar. 
2. LingvoSoft Online. Long Island City: Ectaco Corporate Center. Visited on 7 January 2012, <http:// www.lingvozone.com/LingvoSoft-Online-English-Arabic-Dictionary>

3. <http://dictionary.sakhr.com/SearchResults.aspx>.

4. English $<->$ Arabic Online Dictionary - Ectaco UK. Long Island City: Ectaco Corporate Center. Visited on 7 January 2012, <http://online.ectaco.co.uk/main.jsp?do=e-services-dictionaries word_translate1\&status=translate\&lang1 $=23 \&$ lang $2=$ ar\&source_id $=2118988>$.

5. BA'LAвAкKī, Munīr (2005): al-Mawrid: qāmūs Inkilīzī-'Arabì. Bayrūt: Dār al-'Ilm lil-Malāyīn.

6. The typography for these entries is kept in its original form and the content is similar to that of their printed forms.

7. Oxford Advanced Learner's Dictionary. Oxford: Oxford University Press. Consulted on 10 december 2012, <http://oald8.oxfordlearnersdictionaries.com/dictionary/destruction>

8. Cambridge Advanced Learner's Dictionary \& Thesaurus. Consulted on 10 december 2012, <http:// dictionary.cambridge.org/dictionary/british/destruction?q=destruction\#>

9. Murray, James, Simpson, J. A., and Weiner, E. S. C. (1989). Oxford English Dictionary. 2nd ed. Oxford: Clarendon Press. Note that it does exist an online version as well. See $<$ http://www.oed. $\mathrm{com} /$ view/Entry/51117? redirectedFrom=destruction\#eid $>$.

10. At the time of publication of this article, the corpus is in the vicinity of 7.5 million tokens.

11. Here, the fact that a great deal of UN texts, especially those issued by the General Assembly and the Security Council, are already divided into small numbered paragraphs makes their alignment easier and more accurate. Some other texts were easily divided into clear-cut paragraphs though their paragraphs are not already numbered. This is the case with texts produced by organizations such as UNESCO (United Nations Educational, Scientific and Cultural Organization) and UNICEF (United Nations of International Children's Emergency Fund). The only difficulty in the segmentation and alignment process came with long paragraphs in some IMF (International Monetary Fund) and UNIDO (United Nations Industrial Development Organization) publications, which for practical reasons, have been further divided into smaller paragraphs. But the real challenge was to decide at which point and on which basis such paragraphs are to be divided.

12. Anthony Laurence's Website, The AntConc Homepage. Visited on 12 december 2012, <http://www. antlab.sci.waseda.ac.jp/antconc_index.html>.

AntConc is not tied to any particular language and can be used with English-Arabic texts. The Unicode utf8 encoding must be selectd instead of Western Europe "Latin1" (iso-8859-1).

13. The adjective 'polysemous' is used in Pustejovsky (1995) to qualify both a word and a sense. A polysemous sense is one which is exhibited along with others by the same word.

\section{REFERENCES}

Allerton, David J. (1984): Three (or four) levels of word co-occurrence restriction. Lingua. 63:17-40.

Anthony, Laurence (2006): Concordancing with AntConc: An Introduction to Tools and Techniques in Corpus Linguistics. JACET Newsletter. (55):2085.

BAKER, Mona (1992): In other words: a coursebook on translation. London/New York: Routledge.

BAKER, Mona (1993): Corpus Linguistics and Translation Studies: Implications and Applications. In: Mona Baker, Gill Francis and Elena Tognini-Bonelli, eds. Text and Technology: In Honour of John Sinclair. Amsterdam/Philadelphia: John Benjamins, 233-250.

Baker, Mona (1996): Corpus-based Translation Studies: The Challenges that Lie Ahead. In: Harold Somers, eds. Terminology, LSP and Translation: Studies in Language Engineering in Honour of Juan C. Sager. Amsterdam/Philadelphia: John Benjamins, 175-186.

BAKer, Mona (1998): Norms. In: Mona BAKer, ed. Routledge Encyclopedia of Translation Studies, London/New York: Routledge, 163-165.

Baker, Mona (2003): Corpus-based Translation Studies in the Academy. In: Heidrun Gerzymisch-Arbogast, Eva Hajicová, Petr Sgall, Zuzana Jetmarová, Annely Rothregel and Dorothee Rothfuss-Bastian, eds. Textologie und Translation: Jahrbuch Übersetzen und Dolmetschen 4/II, Tübingen: Gunter Narr, 7-15.

CARTER, Ronald Allan (1998): Vocabulary: Applied linguistic perspectives. $2^{\text {nd }}$ ed. London: Routledge.

Church, Kenneth Ward and Hanks, Patrick (1990): Word association norms, mutualinformation and lexicography. Computational Linguistics. 16(1):22-29. 
Cruse, D. Alan. (1986): Lexical Semantics. Cambridge: Cambridge University Press.

Di Marco, Chrysanne, Hirst, Graeme and Stede, Manfred (1993): The semantic and stylistic differentiation of synonyms and near-synonyms. AAAI Spring Symposium on Building Lexicons forMachine Translation. AAAI Technical Report SS-93-02, 120-127.

FirTh, John Rupert (1957): A synopsis of linguistic theory, 1930-1955. In: Philological SociETY. Studies in Linguistic Analysis. Oxford: Basil Blackwell, 1-32.

Kenny, Dorothy (2001): Lexis and Creativity in Translation. A Corpus-based Study. Manchester: St. Jerome Publishing.

Kenny, Dorothy (2009): Corpora. In: Mona Baker and Gabriela Saldanha, eds. Routledge Encyclopedia of Translation Studies. $2^{\text {nd }}$ ed. Oxford: Taylor \& Francis, 59-62.

Laviosa, Sara (1997): How Comparable Can 'Comparable Corpora’ Be? Target. 9(2):289-319.

Laviosa, Sara (1998): The Corpus-based Approach: A New Paradigm in Translation Studies. Meta. 43(4):474-479.

Laviosa, Sara (2002): Corpus-based Translation Studies: Theory, Findings, Applications. Amsterdam/New York: Rodopi.

Lyons, John (1995). Linguistic Semantics. An Introduction. Cambridge: Cambridge University Press. MalmkjÆr, Kristen (1998): Love thy Neighbour: Will Parallel Corpora Endear Linguists to Translators? Meta 43(4):534-541.

Meyer, Charles F. (2002) English Corpus Linguistics. Cambridge: Cambridge University Press. Pustejovsky, James (1991): The Generative Lexicon. Computational Linguistics. 17(4):409-441. Pustejovsky, James (1993a): Type Coercion and Lexical Selection. In: James Pustejovsky, ed. Semantics and the Lexicon. Dordrecht: Kluwer Academic Publishers, 73-94.

Pustejovsky, James (1993): Semantics and the lexicon. Dordrecht: Kluwer Academic Press.

Pustejovsky, James (1995): The Generative Lexicon, Cambridge: MIT Press.

Pustejovsky, James and Jezek, Elisabetta (2008): Semantic Coercion in Language: Beyond Distributional Analysis. Rivista di Linguistica. 20(1):181-214.

Rosch, Eleanor (1973): Natural categories, Cognitive Psychology. 4:328-350.

SAlHi, Hammouda (2005): Logical Polysemy and Human Translation. Master thesis, unpublished. Tunis: University of Carthage.

SALHI, Hammouda (2010): Small Parallel Corpora in an English-Arabic Translation Classroom: No Need to Reinvent the Wheel in the Era of Globalization. In: Said M ShIYAB, Marilyn Gaddis Rose, Juliane House, and John Duval, ed. Globalisation and Aspects of Translation. Newcastle: Cambridge Scholars Publishing, 53-67.

SAlHI, Hammouda (2012): Investigating Lexical Ambiguity in and through Translation: a Corpus-based Study. PhD thesis, unpublished. Tunis: University of Carthage.

SinclaIR, John (1991): Corpus, concordance, collocation. Oxford: Oxford University Press.

Sinclair, John (1998): Large corpus research and foreign language teaching. In: Robert De Beaugrande, Meta Grosman and Barbara Seidlhofer, eds. Language Policy and Language Education in Emerging Nations. Advances in Discourse Processes, vol. LXIII. Stamford: Ablex, 79-86.

Sinclair, John (1999): The lexical item. In: Edda Weigand, ed. Contrastive Lexical Semantics. Current Issues in Linguistic Theory, vol. 17. Amsterdam/Philadelphia: John Benjamins, 1-24.

Snell-Hornby, Mary (1988): Translation Studies: An Integrated Approach. Amesterdam/ Philadelphie: John Benjamins.

Stubвs, Michael (2001): Words and Phrases: Corpus Studies of Lexical Semantics. Oxford: Blackwell Publishers.

WeINREICH, Uriel (1964): Webster's Third: a critique of its semantics. International Journal of American Linguistics. 30:405-409.

Zanettin, Federico (2002): Corpora for translation practice. In: Elia Yuste-Rodrigo, ed. Language Resources for Translation Work and Research. (LREC 2002 Workshop Proceedings, Las Palmas de Gran Canaria, 29-31 May 2002), 10-14.

Zanettin, Federico, Bernardini, Silvia and Stewart, Dominic, eds. (2003): Corpora in Translator Education. Manchester/Northampton: St Jerome. 